\title{
Religious sites and events as resources for tourism development in cities - case study: Novi Bečej
}

\author{
Dunja Demirović $^{*}$, Marija Cimbaljević ${ }^{2}$ Aleksandra Vujko ${ }^{3}$ \\ ${ }^{1}$ Geographical Institute „Jovan Cvijić“ SASA, Belgrade \\ ${ }^{2}$ University of Novi Sad, Faculty of Sciences, Department of Geography, Tourism and Hotel \\ Management, Novi Sad \\ ${ }^{3}$ Higher School of Professional Business Studies, Novi Sad
}

\begin{abstract}
A large number of tourists are traveling motivated by the desire to learn about the historical and cultural heritage of cities which represent achievements in various fields of art. The volume of tourist traffic in cities depends on the wealth of cultural and historical monuments, environmental, events and other various contents which are concentrated in them. This paper analyzes all religious objects and events that are located in the municipality of Novi Bečej (Serbia) and have importance for tourism development in order to create tourist values of these objects. 100 tourists were interviewed to determine the motives for visiting the municipality of Novi Bečej and to assess the significance of religious objects and events for tourism development from demand side. Based on the survey results, a SWOT analysis was made in order to provide direction for the further development of tourism in the municipality of Novi Bečej. Based on the evaluation of all the elements (tourist and geographical position, artistic value, ambiance, attractiveness, construction and fitting of tourism sites) and performed valuation, it was found that the municipality has a very good quality of cultural sites which distinguish the broader regional importance.
\end{abstract}

Keywords: city, religious objects, events, tourism, municipality of Novi Bečej (Serbia) JEL classification: Z32

\section{Verski objekti i događaji kao osnova za razvoj turizma u gradovima - studija slučaja: Novi Bečej}

Sažetak: Veliki broj turista putuje motivisan željom da se upozna sa istorijskim i kulturnim nasleđem gradova, koja predstavljaju dostignuća u različitim oblastima umetnosti. Obim turističkog prometa u gradovima zavisi od atraktivnosti kulturnih i istorijskih spomenika, okoline, događaja i drugih različitih sadržaja koji su u njima koncentrisani. Ovaj rad analizira sve verske objekte i događaje koji se nalaze u opštini Novi Bečej (Srbija) i imaju značaj za razvoj turizma kako bi se kreirale turističke vrednosti ovih objekata. Intervjuisano je 100 turista kako bi se utvrdili motivi za posetu opštini Novi Bečej i procenio značaj verskih objekata i događaja za razvoj turizma sa strane potražnje. Na osnovu rezultata istraživanja, napravljena je SWOT analiza kako bi se obezbedio pravac daljeg razvoja turizma u opštini Novi Bečej. Na osnovu procene svih elemenata (turistički i geografski položaj, umetnička vrednost, ambijent, atraktivnost, izgradnja turističkih mesta) i izvršene procene, utvrđeno je

\footnotetext{
* d.demirovic@gi.sanu.ac.rs

** The research was supported by the Ministry of Education, Science and Technological Development, Republic of Serbia (Grant III 47007 - „Geography of Serbia“)
} 
da opština ima zadovoljavajuću atraktivnost verskih objekata i događaja, te da oni mogu imati širi regionalni značaj za razvoj turizma.

Ključne reči: grad, verski objekti, događaji, turizam, opština Novi Bečej (Srbija) JEL klasifikacija: Z32

\section{Introduction}

Cultural attractions are elements of the offer which often have decisive influence on the choice of a destination. Culture has existed since the beginnings of the society and it has left traces of their existence in a form of cultural heritage. The cultural heritage of a society consists of monuments, stories, songs and folk dances that are transmitted from generation to generation. Heritage includes the material and spiritual culture of one nation (Csapo, 2012).

Cultural tourism includes such type of tourism in which tourists visit museums, galleries, concerts, or it is related to different forms of material heritage. Tourism has been the main means of cultural exchange, because it provides tourists experience related not only to the past but also contemporary cultural and social life of destination that tourists visit (Russo \& Borg, 2002; Antić, 2017).

From the interactions that occur in the tourist encounters with the local population, new ways of communicating, new knowledge and new values can be created. Upon that kind of impact, tourists to locals and vice versa, depends the success of the development of tourism in the destination. The main challenge in cultural tourism is therefore included in finding ways to revive and activate the cultural potential of the local community (Besculides et al., 2002; Ioan-Franc \& Iștoc, 2007).

This paper analyzes the potential of Novi Bečej for the development of cultural tourism using potential of religious facilities and religious events. The tourist evaluation of these tourism resources was done, the survey among tourists, who visited Novi Bečej, about the possibilities of development of this type of tourism in Novi Bečej was conducted and SWOT analysis was made in order to overcome the shortcomings and boost positive aspects by developing cultural tourism in this city.

\section{Background}

Urbanization is a global process, the main force of development of cities, where people live, work and buy. Cities function as places where the population concentration is determined by space, economic activities are located in the same area or nearby, providing an opportunity for the production and consumption of goods and services. Cities provide different social, cultural and economic activities that attract people, and tourism is one of the main service activities (Bock, 2015).

About $46 \%$ of the world population lives in cities and according to the forecasts, it is considered that in 2030 this number will increase to $61 \%$. These results show an increase in the importance of urban places for tourists' consumption (Page \& Hall, 2003).

City tourism can be characterized as tourism which in general takes the form of cultural trends, and this is precisely the most massive form of the cultural movement of tourists, as the urban areas are complex cultural or anthropogenic tourist values. The volume of tourist traffic in cities depends on the wealth of cultural and historical monuments, environmental, manifestational and other diverse cultural events which are concentrated in them (PaskalevaShapira, 2007; Zmyślony, 2011) (Table 1). 
City tourism' trends are characterized by relatively short stays, and it reaffirms their cultural landmark, as cultural tourism needs are met in a relatively short time - observing, watching, learning about it and experiencing. According to Richards (2010): "Culture and tourism are the two main growing industry of the twentieth century, and by the end of the century a combination of these two sectors in the "cultural tourism" has become one of the most desirable option for developing countries and regions around the world" (pp. 3).

Table 1: Attractive factors for visiting city

\begin{tabular}{|l|l|}
\hline \multicolumn{1}{|c|}{ The main (basic) pull factors } & \multicolumn{1}{|c|}{ Specific pull factors } \\
\hline Rarity and interestingness & $\begin{array}{l}\text { A lot of things to be seen; interesting places; unique } \\
\text { experience }\end{array}$ \\
\hline Cultural attractions, sightseeing & $\begin{array}{l}\text { Interesting architecture; history; excellent museums and } \\
\text { galleries; interesting locals; different cultures and ways of } \\
\text { life; local customs and tradition }\end{array}$ \\
\hline Entertainment & $\begin{array}{l}\text { Exciting nightlife; exciting shopping; live music; theater } \\
\text { and art; popular festivals and events }\end{array}$ \\
\hline Food and accommodation & $\begin{array}{l}\text { Good hotels, sophisticated restaurants, a typical } \\
\text { gastronomy }\end{array}$ \\
\hline
\end{tabular}

Source: Page \& Hall, 2003.

Attractions in the form of heritage such as: attractions (monuments, historical buildings, archaeological sites); religious attractions (churches, cathedrals, temples, etc.); industrial heritage (mines, factories, etc.); literary heritage (birthplaces or homes of famous writers); artistic heritage, and various cultural attractions in the form of traditional festivals, events, folklore, attract many visitors. Visits to the important religious sites and events are carried out to encourage participants to travel more to strengthen their faith. This means that the main motive of these trips is satisfying spiritual or religious needs of people.

Characteristics of tourists who are interested in modern heritage tourism are as follows (Berki \& Csapo, 2008):

- Represented mainly by tourists with higher education;

- Specific consumption of these tourists is higher than average;

- Tourists come from urban areas and from more developed "western world";

- Most of the tourists are in their middle ages and without children;

- According to the length of stay, it might be concluded that in the case of cultural tourism the time allotted for the trip is shorter, while the frequency of the trips is higher.

Products of cultural tourism will be able to survive and to attract more and more tourists - of course taking into account the basic principles of sustainable tourism - by using competitive product development of cultural tourism, which is mainly based on the quality, uniqueness, creativity and economic benefits (Ontario Cultural and Heritage Tourism Product Research Paper, 2009).

The municipality of Novi Bečej is located in the center of Vojvodina province (Serbia) and is one of the five municipalities in the middle Banat region. The municipality comprises four settlements: Novi Bečej, Novo Miloševo, Kumane and Bočar.

Novi Bečej is situated on the left bank of the river Tisza on the $66^{\text {th }}$ kilometer from its confluence with the Danube River, and is the only town on the Tisza whose center is on the river. With regard to the national position (considered in relation to Belgrade, as the capital city of the Republic of Serbia), the municipality is characterized by favorable position. Belgrade is the strongest tourist market and good connections can affect the intensive tourist excursion. Good relations with Belgrade and a good tourist geographic position within Vojvodina make an emitting area of Novi Bečej, which in this case has about 4 million inhabitants. 
On the basis of census from 2011, the population of the municipality of Novi Bečej is 24.455 inhabitants. In the ethnic structure of the population, most notable are the Serbs $(69.94 \%)$ and Hungarians (19.22\%).

In the area of Novi Bečej, diverse economies are developed. Among the industries dominate agriculture and industry, and in the last few years, increasing attention has been paid to transport, trade, catering and tourism.

The municipality of Novi Bečej is an area with a long history, and therefore has a very large number of religious buildings. The municipality has seven Orthodox religious objects, four Catholic religious sites and the remains of a medieval Romanesque churches. Some of the most important religious sites for tourism development in Novi Bečej are (Strategija razvoja turizma opštine Novi Bečej, 2009):

- The chapel "Monastery" was built in the eighteenth century as a single-nave building with a semicircular apse and a tower above the western part of the temple. The greatest value of Novi Bečej's chapel is made from material preserved from the old temple. Particularly interesting is a triptych from the beginning of the eighteenth century (preserved in 1965), which bears on the central field of play Sv. George Killing the Dragon, while the side wings displayed scenes from the saint's life. At the chapel, protection works were carried out in 1969, 1975, 1979 and 1987, and the work was undertaken by the Institute for Protection of Cultural Monuments of Zrenjanin city.

- The Catholic Church of St. Clara of Assisi is a catholic chapel built in 1747 from adobe, the place where today's Catholic Church in Novi Bečej is. The current Catholic church was built from Clara's donation in the period from 1804 to 1809 . The new church at the request of donors was dedicated to Clara of Assisi, and to a former patron of the former chapel, St. Valentine, is dedicated a special altar.

- The remains of the medieval Romanesque churches Arača - there are no data that reliably show the time of occurrence of this church. Since the beginning of the eighteenth century, when the Turks left Banat, was in ruins. The basis of this impressive church and spatial distribution is characteristic of the Franciscan church (semi-circular, shallow pointed harbor and narrow, semicircular windows), suggesting that it was built in the late twelfth or early thirteenth century. During excavations in 1879 in Arača, it was discovered a tombstone with the performance of the saints and donors, decorated interweave three-member band, which was dated to the XII century. Recent archaeological research confirms that on the north side there were many residences and tombs.

Religious events are held in the municipality every year, such as Assumption of the Mother of God ("Velika Gospojina"), St. Elias ("Sveti Ilija") and the church celebration St. StefanReligious tourism events are those that have an attractive religious content and significance. They may be associated with certain religious holidays (Christmas, Easter) or places designated for performing religious rites and events from the history of the church, marking significant dates of the prophets, apostles, saints. Religious and historical events are those that besides religious and ethnographic characters, have historical significance. On this occasion, worship takes place, performing the ritual with usually important church dignitaries. In church or in front of it, is a kind of national parliament, within which are held applications based on folklore and traditions of the city or region (Bjeljac, 2006).

Serbian Orthodox Church celebrates the feast of the Assumption. It belongs to the immovable church holidays (at $28^{\text {th }}$ August). The Assumption as a village celebration of Novi Bečej has started to be held from 1994. For this celebration, the city of Novi Bečej has combined different cultural and entertainment events: the traditional and the modern, culture and sports, past and future. 


\section{Materials and Methods}

The aim of this paper is to analyze all the religious objects that are located in Novi Bečej and events that are associated with religious holidays and religious objects, which can provide a great opportunity for the development of cultural and religious tourism.

The aim of this paper is to present all religious sites in Novi Bečej, to point out their inestimable value, as well as to highlight the elements that would lead to the valorisation of religious buildings, and the development of tourism in this area. The aim of this paper is: to get acquainted with the natural and social characteristics of Novi Bečej, to get acquainted with the basic concepts of cultural tourism, its division, elements and importance within the tourism industry, to become familiar with the concept of religious tourism, to analyze to what extent is possible to develop cultural tourism in this area, and to analyze and evaluate religious facilities.

\section{Results and Discussion}

Tourist valorization presents a detailed assessment of natural and anthropogenic values of importance to the development of tourism at one site, in one center, a place, geographical region or country as a whole. Novi Bečej with its natural and anthropogenic characteristics has the potential to develop different forms of tourism.

Among all anthropogenic tourist values, religious buildings occupy an important place in their number, but also its values..

On the basis of the analysis of the basic elements of tourist valorization, the assessment of these elements is the next step, and all this in order to form the tourist value of the anthropogenic values. For comparison, religious objects in Novi Bečej were taken (Table 2).

The evaluation was performed for each unit individually, as follows:

- score 1 - insufficient quality, it is not for the tourist presentation,

- score 2 - quality satisfies, a local tourist importance,

- score 3 - good quality, regional character,

- score 4 - very good quality, a wider regional importance,

- score 5 - excellent quality, international tourist significance.

Table 2: Valorization of religious sites in Novi Bečej

\begin{tabular}{|c|c|c|c|c|c|c|c|}
\hline $\begin{array}{l}\text { Cultural } \\
\text { complex }\end{array}$ & $\begin{array}{l}\text { Tourism } \\
\text { position }\end{array}$ & $\begin{array}{l}\text { Artistic } \\
\text { value }\end{array}$ & Environment & Attractiveness & $\begin{array}{c}\text { Degree of } \\
\text { development }\end{array}$ & Incorporation & $\begin{array}{c}\text { General } \\
\text { tour. } \\
\text { value }\end{array}$ \\
\hline $\begin{array}{c}\text { Chapel } \\
\text { "Monastery" }\end{array}$ & 4 & 5 & 5 & 5 & 4 & 5 & 4.66 \\
\hline $\begin{array}{l}\text { The Church of } \\
\text { St. John the } \\
\text { Precursor }\end{array}$ & 3 & 5 & 3 & 3 & 2 & 4 & 3.33 \\
\hline $\begin{array}{l}\text { The Church of } \\
\text { St. Nikola }\end{array}$ & 5 & 5 & 5 & 5 & 5 & 5 & 5.00 \\
\hline $\begin{array}{l}\text { The Catholic } \\
\text { Church of St. } \\
\text { Clara of Assisi }\end{array}$ & 5 & 4 & 5 & 3 & 3 & 4 & 4.00 \\
\hline $\begin{array}{l}\text { The Catholic } \\
\text { Church of St. } \\
\text { Ištvan Kiralj }\end{array}$ & 3 & 5 & 3 & 3 & 2 & 4 & 3.33 \\
\hline $\begin{array}{l}\text { The remains of } \\
\text { the medieval } \\
\text { Romanesque } \\
\text { churches Arača }\end{array}$ & 4 & 5 & 5 & 5 & 1 & 2 & 3.66 \\
\hline $\begin{array}{c}\text { The average } \\
\text { value }\end{array}$ & 4,00 & 4,83 & 4,33 & 4,00 & 2.83 & 4.00 & 3.99 \\
\hline
\end{tabular}

Source: Authors' personal assessment 
Based on the evaluation of all the elements, a general assessment of their tourist value was made, which amounts to 3.99 , indicating a very good quality, which means that religious sites in Novi Bečej have wider regional importance. The highest values have artistic value and the incorporation of the tourist wealth and they are characterized by very good quality and a wider regional importance.

In this area there are basic conditions for the development and presentation of the destination. It is necessary to take the needed measures in order to raise the quality of tourism, and to take advantage of the possibilities offered by these places of worship, because only well-preserved and protected objects represent real tourist value.

SWOT analysis is a technique of strategic management, which is identified by the strategic choices, bringing the bond strengths and weaknesses of the company with the opportunities and threats in the external environment (Table 3).

Table 3: SWOT analysis of religious facilities and religious events in Novi Bečej

\begin{tabular}{|c|c|}
\hline Strengths & Weaknesses \\
\hline $\begin{array}{l}\text { - geographical position, } \\
\text { - vicinity of the borders, } \\
\text { - a favorable climate, } \\
\text { - the attractiveness of natural factors, } \\
\text { - wealth anthropogenic factors, } \\
\text { - religious events, } \\
\text { - multicultural environment, } \\
\text { - Ramsar site, } \\
\text { - the phenomenon of flowering in the Tisza } \\
\text { river, } \\
\text { - proximity to Corridor } 10, \\
\text { - good tourist signaling in the municipality }\end{array}$ & $\begin{array}{l}\text { - under-utilization of the Tisza and canals for } \\
\text { tourism purposes, } \\
\text { - the lack of a plan for tourism development, } \\
\text { - lack of expertise of personnel employed in } \\
\text { tourism, } \\
\text { - a small number of accommodation facilities, } \\
\text { - the poor quality of roads, } \\
\text { - lack of tourist propaganda, } \\
\text { - no monitoring of tourist traffic, } \\
\text { - there is not a tourist product that would } \\
\text { consolidate all the resources }\end{array}$ \\
\hline Opportunities & Threats \\
\hline $\begin{array}{l}\text { - investment in infrastructure, } \\
\text { - training and education of tourism staff, } \\
\text { - raising awareness of local population } \\
\text { about the cultural and historical } \\
\text { significance of resources, } \\
\text { - a significant proportion of hunting } \\
\text { tourism in the overall tourist offer, } \\
\text { - Development of small and medium-sized } \\
\text { enterprises in this area, } \\
\text { - Employment of local residents }\end{array}$ & $\begin{array}{l}\text { - economic crisis, } \\
\text { - lack of funds for the development of local and } \\
\text { international infrastructure, } \\
\text { - competition of similar cities (with similar } \\
\text { characteristics, anthropogenic) in the } \\
\text { environment, } \\
\text { - more developed nautical traffic in the Hungarian } \\
\text { part of the Tisza, } \\
\text { - quality roads in neighboring countries }\end{array}$ \\
\hline
\end{tabular}

Source: Authors

Advantages - The geographical position of Novi Bečej is very good, because it is located on the main road Kikinda-Novi Sad, Kikinda-Zrenjanin, and a new bridge at Ada connects the villages with Subotica (Bačka region). Very close is the Romanian border (about $25 \mathrm{~km}$ ) and Hungary $(70 \mathrm{~km})$. The region's climate is very favorable for the development of cultural tourism, events, excursions and other forms of tourist movements, because all four seasons are represented in this region. The municipality has a very long history, and therefore has a lot of anthropogenic factors, which have already been mentioned in the paper. Religious events are events that are recognizable in the region and that offer the city a possibility for easier development and promotion of cultural tourism. 
Multiculturalism in the municipality, which currently has about a dozen nations, can also be a very attractive motive for visitors from abroad. like. The Ramsar Convention was adopted in 1971, and is the action in the national and international context, with regard to the protection and wise management of wet areas and their resources (Salt Kopovo).

The phenomenon of Tisza blooming - a natural phenomenon that happens on the banks of the Tisza around Kanjiža city almost every year, depending on water temperature and water level. People call this phenomenon a "blossom river". It is not about water plant but about an insect, called the flower prints or Palngenia longicauda whose mate is a natural phenomenon that occurs on the entire Tisa. Besides this, the city has a very good traffic signs and road signs.

Weaknesses - the Tisza River is still poorly used, or even untapped to tourism purposes. The municipality has a plan, which refers to the involvement of all the villages in the development of cultural tourism in this area, and which the Tourist Organization of the Municipality of Novi Bečej has been working on. In Novi Becej there is the tourism organization, where visitors can be able to inquire about cultural resources. The municipality has a very small percentage of accommodation facilities (Hotel Tisa Flower, Hunter and Azucki).

When it comes to the road infrastructure, it is invested only when it is no longer safe for a safe trip. There is a site of the municipality of Novi Bečej which provides basic information about the history, culture, and tradition. The number of visitors is not recorded during a visit. In the municipality there is no tourist product that would consolidate all the resources, and represent a complex entirety.

Threats - The development of cultural tourism depends largely on the economic crisis and the lack of money. Threats to the development of cultural tourism in the city of Novi Bečej are also the surrounding cities (Kikinda, Temerin, Mokrin) that invest much more in the development of tourism. Nautical traffic in the Hungarian part of the Tisza river is much more developed than in Novi Bečej, and when it comes to the land transport, neighboring countries have a much better infrastructure, which facilitates the development of tourism.

A survey research was carried out in Novi Bečej and 100 tourists were surveyed - of whom 42 were men (42\%) and 58 women (58\%). Of all the 100 respondents, from Novi Sad were 28 respondents $(28 \%)$, from Belgrade 30 respondents $(30 \%)$, from Subotica there were 22 respondents (22\%), and from Zrenjanin city 20 respondents (20\%).

Novi Bečej has the opportunity to develop cultural tourism according to 84 tourists (84\%), while the remaining 16 respondents $(16 \%)$ think that the city does not have a large number of cultural resources for cultural tourism development. This shows that some respondents are not familiar with what can be included in the development of cultural tourism in this city.

Tourists were asked if they visited religious buildings in the municipality, and 80 respondents $(80 \%)$ visited some religious object. Also, tourists were asked if they visited a religious event, and 94 participants visited a religious event, while 6 respondents did not see a single event in the municipality. Most tourists visited Assumption days, followed by a village feast St. Ilija, and the Church main feast St. Stefan.

The opinion of respondents on the importance of religious buildings was divided - 21 respondents believe that religious buildings in the municipality have local significance (21\%), 46 respondents believe that cultural objects have a regional character (46\%), while 15 respondents believe that cultural goods of Novi Bečej have international importance (15\%) (Figure 1). 
Figure 1: The importance of religious objects for tourism in Novi Bečej

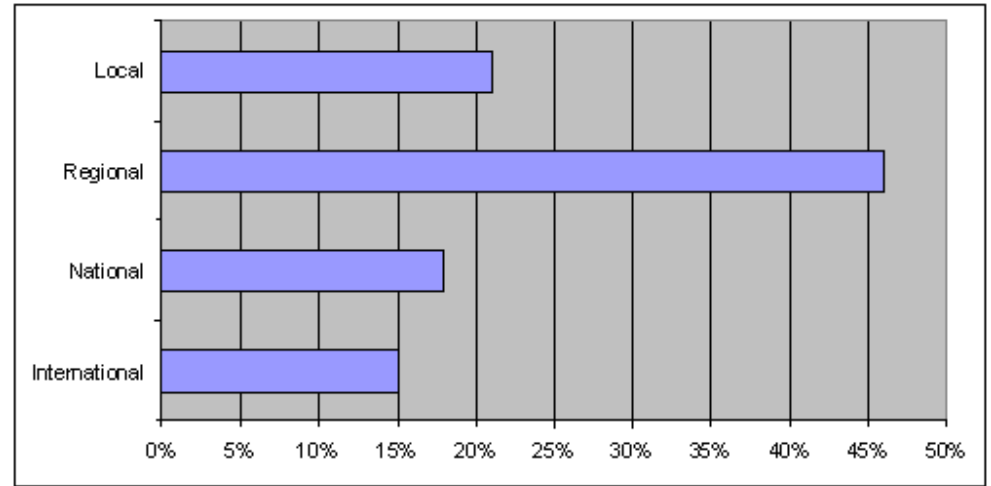

Source: Authors based on processing data of the survey research

Of the 100 respondents, 91 respondents would like that cultural tourism is developed in the municipality, while nine respondents answered negatively to this question.

\section{Conclusion}

Thanks to centuries of human residence in the territory of Novi Bečej, today, still can be seen the remains of archaeological sites, fortresses, churches and castles, which have immeasurable value for the people of this region, and which speak about the rich history, culture, and traditions of this nation, and are attractive for tourists. Although there are cultural assets that may be factors of promoting and developing cultural tourism in Novi Bečej, the present level of tourism is at a low level of development.

Based on the evaluation of all elements (tourist and geographical position, artistic value, environment, attractiveness, degree of development and incorporation), and performed valuation, it was found that the city has a very good quality of cultural goods, which are characterized by wider regional importance. In this area there are basic elements for the development and promotion of cultural tourism. Based on a survey research, it was found that most tourists are familiar with the concept of cultural tourism, as well as they agree that Novi Bečej has a great possibility for the development of this form of tourism. From the results, it was concluded that tourists are not satisfied with the existing level of affirmation of cultural assets and the quality of the organization of certain events. What is necessary for the further tourism development is to create an infrastructure that would allow adequate access to cultural property, then planning and arranging their immediate environment, investment in advertising materials, increase in the number of restaurants, and creating the image of the municipality which will be unique and distinctive. All these elements will enable the improvement of living standards of the local population and raising awareness about the importance of the cultural and historical attractions of this municipality, will attract investors, which in turn will lead to the development of small and medium-sized enterprises.

\section{References}

1. Antić, A. (2017). Mogućnosti za razvoj ekoturizma sa komplementarnim kulturnim nasleđem: studija slučaja, spomen park Čačalica [Opportunities for ecotourism development with complementary cultural heritage: The case study of Čačalica Memorial Park]. Menadžment u hotelijerstvu i turizmu, 5(2), 85-95. 
2. Berki, M. \& Csapó, J. (2008). The Geographical Basis for the Development of Thematic Routes. In Z. Dövényi (Ed.), Progress in Geography in the European Capital of Culture 2010 (pp. 161-173). Pécs: University of Geography - University of Pécs.

3. Besculides, A., Lee, M. E. \& McCormick, P. J. (2002). Residents' perceptions of the cultural benefits of tourism. Annals of Tourism Research, 29(2), 303-319. https://doi.org/10.1016/S0160-7383(01)00066-4

4. Bjeljac, Ž. (2006). Teorijsko-metodološke osnove manifestacionog turizma [Theoretical and methodological basics of event tourism]. Belgrade: Geographical Institute „Jovan Cvijic“" SASA.

5. Bock, K. (2015). The changing nature of city tourism and its possible implications for the future of cities. Eur J Futures Res, 3, 20-28.

https://doi.org/10.1007/s40309-015-0078-5

6. Csapo, J. (2012). The Role and Importance of Cultural Tourism in Modern Tourism Industry. In M. Kasimoglu \& H. Aydin (Eds.): Strategies for Tourism Industry Micro and Macro Perspectives (pp. 201-232). Rijeka: InTech.

7. Ioan-Franc, V. \& Iştoc, E. M. (2007). Cultural tourism and sustainable development. Romanian Journal of Economic Forecasting, 1, 89-96.

8. Ontario Cultural and Heritage Tourism Product Research Paper (2009). Ontario: Queen's Printer for Ontario. Retrieved September 15, 2018 from http://www.mtc.gov.on.ca/en/publications/Ontario_Cultural_and_Heritage_Tourism.p df

9. Page, S. \& Hall, C. M. (2003). Managing Urban Tourism. Harlow: Prentice-Hall.

10. Paskaleva-Shapira, K. A. (2007). New Paradigms in City Tourism Management: Redefining Destination Promotion. Journal of Travel Research, 46(1), 108-114. https://doi.org/10.1177/0047287507302394

11. Richards, G. (2010). Tourism development trajectories - From culture to creativity? Encontros Científicos, 6, 9-15.

12. Russo, A. P. \& der Borg, J. (2002). Planning considerations for cultural tourism: a case study of four European cities. Tourism Management, 23(6), 631-637. https://doi.org/10.1016/S0261-5177(02)00027-4

13. Strategija razvoja turizma opštine Novi Bečej [Strategy for tourism development of Novi Bečej municipality] (2009). Novi Sad: Faculty of Sport and Tourism. Retrieved September 21, 2018 from http://novibecej.rs/dokumenta/strategija_razvoja_turizma.pdf

14. Zmyślony, P. (2011). Globalization, tourism and cities: pros and cons. Folia Turistica, 25(1), 299-312. 